\author{
PETER MEEL
}

\title{
ANTON DE KOM AND THE FORMATIVE PHASE OF SURINAMESE DECOLONIZATION
}

Wij slaven van Suriname (We slaves of Suriname) by Anton de Kom (18981945) stands out as one of the classics of Surinamese historiography and one of the most debated books among contemporary scholars involved in Surinamese studies. ${ }^{1}$ Remarkably, the work obtained this high-profile status only recently. At the time of publication (1934) Wij slaven van Suriname did not attract an appreciable audience beyond the communist-oriented circle of writers, activists, unionists, and politicians the book ideologically stems from. Discredited by the political establishment and lacking substantial media coverage, not many people in either the Netherlands or in Suriname took note of it. ${ }^{2}$

In the early 1970s Surinamese students in the Netherlands rediscovered Wij slaven van Suriname, labeling the book a landmark in the expression of a true Surinamese anticolonialism. The young Surinamers considered De Kom a forerunner of the nationalism they endorsed and were particularly inspired by his plea for class allegiance and social justice. Back in Suriname these graduates aspired to transform the message of Wij slaven van Suriname into political action. Yet, the political parties they established did not generate the public support they had hoped for. As of the early 1980s, when the

1. Earlier versions of this text were presented at the 40th conference of the Association of Caribbean Historians (ACH) in Paramaribo, Suriname, May 11-15, 2008 and the 6th Caribbean Reasonings Conference in Kingston, Jamaica, June 11-13, 2008. I am indebted to Juanita de Barros, Maurits Hassankhan, Gert Oostindie, and Rosemarijn Hoefte for their useful comments on my ACH paper. Additionally, I benefited from critiques by three anonymous reviewers and from the generous support of Alice Boots and Rob Woortman. They kindly offered me the opportunity to examine the pre-final version of their biography of Anton de Kom, which will be published by the end of 2009.

2. The Dutch authorities rejected the book for ideological reasons and considered their disapproval even more justified when in 1935 a German translation of the work was published in Moscow.

New West Indian Guide / Nieuwe West-Indische Gids vol. 83 no. 3 \& 4 (2009):249-280 
country was under military rule, a number of radical leftist representatives of these parties accepted high positions in the country's administration and declared De Kom a national hero. This official tribute gave rise to reprints of Wij slaven van Suriname, a Spanish edition of the work in Havana, and a growing popular identification of the book with anticolonialist and antiimperialist struggle.

This re-evaluation of De Kom's work was accompanied and sustained by a change in scholarly judgment. From the late 1940s until the beginning of the 1980s, Rudolf van Lier's authoritative social history of Suriname had largely determined the image of De Kom. Adhering to pluralist theory, Van Lier carefully addressed the psychological causes and effects of the 1930s labor disturbances in Suriname that De Kom had been involved in. He termed the author's display of the mentality of the lower-class Surinamer, particularly as demonstrated in the memory of the sufferings endured by the ancestors of the Afro-Surinamese, the chief merit of Wij slaven van Suriname. However, Van Lier (1971:370) also argues that this memory had become "part of a pathetic sense of grievance and a rancor which, however much justified by the circumstances in which the lower classes found themselves, prejudice a proper insight into the past." The author seemed to suggest that De Kom, a representative of these classes himself, clung to a similarly partisan view.

In 1982 Sandew Hira published a book that marked a turning point in the appraisal of Wij slaven van Suriname. Hira severely criticized Van Lier for his support of pluralism and for laying emphasis on ethnic heterogeneity and the importance of Dutch culture for the process of forging a common Surinamese identity. Hira instead favored the adoption of Marxism as a more suitable theoretical framework, indicated that anticolonialism had been the continuous thread in Surinamese history, and promulgated class solidarity as the proper instrument for arriving at a society based on social justice. In his book he called De Kom "the greatest revolutionary of our history" and Wij slaven van Suriname his "literary masterpiece," not only because of its fierce anticolonialism, but particularly because for the first time the book demonstrated "that also our people have a history of resistance which can teach us a lot" (Hira 1982:vii-ix). ${ }^{3}$ It was phrases like these which in the early 1980s - the Republic of Suriname was still in its infancy - coincided with the need for a progressive Surinamer whose writings could give ideological support and inspiration and who could metaphorically direct society toward a more promising future. In the wake of Hira's work, there were many other studies published bestowing upon De Kom the status of a true Surinamer who had operated ahead of his time and had given his life for the ideal of freedom. ${ }^{4}$

3. Oostindie 1990:16-18 discusses the Van Lier-Hira controversy.

4. Upholding this viewpoint, Van Mulier 2008 presents De Kom as a role model for young Surinamers. 
Although an anticolonial stance and leftist notions certainly are main features of Wij slaven van Suriname, an uneven focus on these elements specifically if this focus remains confined to the domain of political rhetoric - obscures the versatility of De Kom's investigation and the complex and intriguing design of the book. In this article I disclose the views and convictions revealed in Wij slaven van Suriname and its innovations from the point of view of historiography. I argue that Wij slaven van Suriname marks a new stage in Surinamese history writing and a novel way of dealing with the Surinamese past. To determine the characteristics of the book and its contribution to Caribbean historiography I juxtapose Wij slaven van Suriname with two other groundbreaking works in Caribbean political thought: Capitalism and Slavery by Eric Williams (1911-1981) and The Black Jacobins by C.L.R. James (1901-1989).

It is not my aim to make an elaborate comparison of the three works. My intention is to trace and single out the particularities of Wij slaven van Suriname, contrasting De Kom's work with the two intellectually adjacent tours de force. Although this implies a quick scan rather than an exhaustive analysis, a brief consideration allows for a more in-depth examination of the principal ideas of Wij slaven van Suriname and will lay bare more thoroughly its inherent qualities and historiographical significance. Consequently, I hope to demonstrate that De Kom's hitherto surprisingly weak Caribbean profile is not justified given that his work represents the formative phase of Surinamese decolonization and therefore deserves a prominent place in twentieth-century Caribbean history writing. ${ }^{5}$

\section{AcCuser's Role and SuRinamese Perspective}

Wij slaven van Suriname is an exceptional book. It is the first work on the history of Suriname written by a Surinamese author from a Surinamese perspective. Moreover, it is the first work presenting a critical view of contemporary Surinamese developments and promoting a model directed at a "reconstruction" of Surinamese society. Finally, it is the first work blending an account of major historical events in Suriname with a strong personal engagement, as testified by snapshots of the author's youth in Suriname and the narrative of his short-lived activist career in his native country. It is this

5. Mainly due to language differences, studies on Caribbean intellectual history often disregard authors connected with the Dutch-speaking Caribbean. See for example Benn 2004, Bolland 2004 and Torres-Saillant 2006, although Torres-Saillant pays random and sketchy attention to Dutch-Caribbean literature, including De Kom's Wij slaven van Suriname. 
combination of elements that lends Wij slaven van Suriname its particular quality and importance.

De Kom was not the first self-made historian of Suriname. In Wij Slaven van Suriname the author explicitly acknowledges that his predecessors provided him with substantial data and valuable insights. Among the publications fundamental to the creation of Wij slaven van Suriname three classic volumes stand out: Geschiedenis van Suriname (History of Suriname, 1861) by Julien Wolbers, a well-known abolitionist and reliable researcher; Beschrijving van Guiana of de Wilde Kust in Zuid-Amerika (Description of Guyana or the Wild Coast in South America, 1770) by Jan Jacob Hartsinck, son of a director of the metropolitan-based Society of Suriname and an accurate compiler of archival documents connected with the seventeenth- and eighteenth-century colonial government; and the world-famous Narrative of a Five Years 'Expedition against the Revolted Negroes of Surinam (1796) by John Gabriel Stedman, an uncompromisingly critical account of the inhuman treatment of the Surinamese slave population, written by a military volunteer of Scottish descent serving in the Dutch army in Suriname and contracted to chase runaway slaves. Apart from these works De Kom in Wij slaven van Suriname relied on other secondary literature, mainly written by Dutch authors, and on a tiny selection of Dutch government reports and Surinamese newspaper articles.

Chronicling Suriname's history from the arrival of the Europeans in the days of Columbus until the sociopolitical crisis of the mid-1930s, De Kom aptly applies the findings presented by Wolbers, Hartsinck, and Stedman to his own work. Yet his working method and aim differ substantially from those of the other authors. Firstly, De Kom's tale is a highly condensed and idiosyncratic version of the lengthy writings of the examples he so admires. In Wij slaven van Suriname many important events and developments are under-studied or simply left out. This is not a consequence of the scarcity of sources available at the time of writing, but a matter of deliberate selection. While preparing his publication, representativeness was not De Kom's objective, and completeness even less. Nor did he intend his work to be a contribution to historical scholarship as he did not cherish any academic ambitions.

An additional difference from the works of his predecessors, Wolbers and Hartsinck in particular, is the tone De Kom uses to unfold the injustices people of his home country had been subject to for such a long time. This tone reflects the accuser's role the author had adopted to make his points. Obviously De Kom in this respect was influenced and sparked by the sweeping catalogue of cruelties toward slaves and maroons by the colonial authorities in eighteenth-century Suriname that Stedman had compiled. The paragraphs dedicated to these abuses in Narrative of a Five Years' Expedition against the Revolted Negroes of Surinam had upset its contemporary readers, the more so because there were drawings accompanying the equally grue- 
some and alarming text. The brutalities had also made an impression on De Kom, who wished to share Stedman's observations with his associates.

In addition to Narrative of a Five Years' Expedition against the Revolted Negroes of Surinam, a little book called Zuid-zuid-west (South-south-west, 1923), written by the Surinamese writer and acclaimed homo universalis Albert Helman (pseudonym of Lou Lichtveld), was a source of inspiration for De Kom. This fine work of lyrical prose had caused a scandal in the Netherlands because it included several unyielding attacks on - what the author deemed to be - the hypocrisy of the Dutch. He argued that in the seventeenth and eighteenth centuries the Dutch had profited immensely from the exploitation of Suriname's natural resources, but particularly following the abolition of slavery in 1863 had increasingly neglected the languishing colony. To Helman's outrage the mother country only reluctantly accepted the obligation of supporting Suriname with financial aid and stubbornly refrained from offering the colony sustainable solutions to its pressing problems.

The echoes of both Stedman and Helman can easily be traced in Wij slaven van Suriname, which contains many a bitter and sarcastic remark as well as grave charges (repeatedly disguised as rhetorical questions) about the economic greed, religious bigotry, cultural barbarism, political unreliability, moral irresponsibility, and legal indifference of the Dutch colonizer. In these paragraphs the author uninhibitedly throws accusations in the faces of those in power and vents his disbelief in the possibility of colonial reform to the benefit of his fellow-countrymen. ${ }^{6}$ De Kom in Wij slaven van Suriname resembles Helman in applying the latter's impassioned and poetical style as demonstrated in Zuid-zuid-west. This is particularly evident from the inclusion in Wij slaven van Suriname of lyrical descriptions of mama Sranan's (mother Suriname's) interior and the incorporation of paragraphs almost imperceptibly crossing the boundaries of nonfiction. ${ }^{7}$

Although the accuser's role De Kom adopted is a remarkable trait of $W i j$ slaven van Suriname the most innovative aspect of the book is the author's employment of a Surinamese perspective. Until the 1930s, the scant body of literature on Surinamese history was largely a reflection of the interest researchers in the metropolis took in the institutional aspects of Suriname's political and economic advances. In their works the native population played a nondescript part. The nonwhite inhabitants of Suriname were portrayed as chance associates of amorphous groups of laborers, contributing to the colony's gross national product, but lacking a distinct profile or features of

6. These lines prompted Oostindie \& Hoefte (1999:612) to accurately label Wij slaven van Suriname a "pervasive and articulate $j$ 'accuse against Dutch colonialism and capitalism."

7. For imaginative, but ultimately fictitious, sections, see De Kom 2003:31-32, 39-40, 69-70, 163-64. 
individuality. De Kom should be credited for his zealous efforts to make up for this omission. Encouraged by the writings of Stedman, Wolbers, and notably Helman, he demonstrates a sincere concern for the common Surinamer and effectively brings this involvement to the forefront in Wij slaven van Suriname. Promoting previously subordinate figures to the level of protagonists, he bestows upon the invisible and powerless a sense of self-esteem and identity.

De Kom was well equipped to give them a new self-confidence, being a descendant of slaves himself. He possessed a natural sympathy for and more importantly - a profound knowledge of the people he wrote about. His experiences as a child and schoolboy raised in a lower-class Afro-Surinamese family in Frimangron, ${ }^{8}$ and later as an adult trying to find a suitable occupation and make a decent living, combined with his immersion in communist ideals in the Netherlands, had made him extremely conscious of the subordination of lower-class Afro-Surinamese in Surinamese society. Thus, De Kom, who was an insider, differed markedly from the outsiders Stedman and Wolbers, the first an engaged but temporary visitor, the second an industrious investigator who never set foot on Surinamese soil. Although as Surinameborn writers both were insiders, De Kom and Helman did not share a common ethnic and class background. Helman's ancestors came from the Para district (generally considered a "negro" district), but they were of mixed rather than of Afro-Surinamese descent. Helman was raised in Paramaribo, in a middle-class family that maintained personal and professional relations with the local elite. He identified with the world beyond his roots, obtained a pre-university education in the Netherlands, and at an early age endorsed a cosmopolitan view of life. As opposed to Helman, De Kom did not live in relative prosperity since his childhood, nor did he benefit from a stimulating intellectual environment. Besides, he would never be part of the establishment, neither in Suriname nor in the Netherlands.

In the first part of Wij slaven van Suriname, "The Era of Slavery," De Kom's perspective is mainly congruent with what can be labeled - using the vocabulary of that time - the "negro perspective." Following some introductory sections on the "red slaves," memorates their horrible fate and pays tribute to the acts of resistance of "these courageous Surinamers," De Kom tells at length of the cruelties of the Middle Passage, the hardships of the slaves ("our fathers") on the plantations, the life of luxury and abundance their masters indulged in, and the excessive punishment the slaves were exposed to. Understandably his anger

8. Freeman's ground, a neighborhood in Paramaribo originally designated for free colored people.

9. Indigenous people living in Suriname's coastal areas who were enslaved with the onset of Dutch colonization. 
and indignation were mainly aimed at the unjust and inhumane treatment the many enslaved men, women, and children suffered.

More specifically, De Kom's criticism affects the deliberate deletion of the "negro past" in the educational programs prevalent in the colony at that time. In history classes in primary and secondary school Surinamese children were taught about the life and times of white metropolitan rulers and administrators in great detail, but information about and explanations of the merits and accomplishments of their ancestors were withheld. De Kom's comment on the psychological effects of this tendentious version of history is unambiguous:

No better means to cultivate the inferiority complex of a race than these history lessons exclusively dedicated to the naming and praising of the sons of another people. It took a long time before I had freed myself completely from the obsession that a negro must always and unconditionally be the inferior of every white man ... No people can fully mature that maintains an inferiority complex as a hereditary defect. For that reason this book attempts to raise the self-respect of the Surinamers and to prove the inaccuracy of the peace intentions of the Dutch at the time of slavery. (De Kom 2003:60) ${ }^{10}$

In Wij slaven van Suriname this quotation cleverly bridges the sections on slavery and marronage, the "peace intentions" serving as a reference to the successive negotiations the colonial authorities initiated to check the revolting maroons. In a number of instances these deliberations resulted in official peace treaties, rightly judged by De Kom as manifestations of divide and conquer, since the pacified maroons had to concede to backward positions in the Surinamese heartland and were compelled to ally with the local government to vanquish their nonpacified fellow maroons.

10. All translations from Wij slaven van Suriname are mine. Only some fragments of the book were previously published in English (see Van Neck-Yoder 1998:667-72). De Kom's contemplation of the inferiority complex of the "negro race" is mirrored in Smeulders 1944. Smeulders (1911-92), a teacher of Surinamese origin who worked in Suriname and Curaçao (see Van Kempen 2003b:27-29), also denounced education as the chief source of the "negro's" shame of his own race. In his book Smeulders (1944:11), building on private information concerning pedagogical abuse in Suriname and Curaçao, unreservedly attacks his fellow-teachers for their color prejudices and acts of racial discrimination: "The majority of the teaching personnel, in other words those who must provide moral guidance, is standing on the wrong side" (my translation). Smeulders advocated a gradual process leading toward full equality between colored and white people, in which education had to play a major role and "negro" role models from the United States had to play a prominent part. Although precocious and outspoken at the time of publication, references to De Kom are not included in Smeulders's work. 
De Kom in his book notably prided himself in paying high tribute to what the colonial authorities deemed "scum," but what he defined as "freedom fighters." Appraising the guerrilla wars maroon leaders waged against the Dutch, De Kom emphasizes the courage, generosity, sense of justice, and art of war these commanders exhibited and takes into consideration their gains and losses in terms of territory, well-being, and quality of life. Furthermore, he commends their efforts to promote the feeling of freedom among their followers. In the 1930s, this respectful approaching of hitherto neglected, if not scorned population groups represented a novel way of dealing with the past. It paved the way for the inclusive and comprehensive version of Suriname's history commonly endorsed in the Republic of Suriname today.

Swept away by his emancipation ideals, De Kom does not consistently resist the temptation of endowing his heroes with mythical proportions. However, at the same time he admits that marronage often lacked the guerrilla features depicted so vividly in his work. Hinting at forms of non-armed resistance centering on inventiveness and cunning, he refers to the well-known allegorical figure of Anansi, the trickster spider, who, sitting on the back of King Tiger, enrages his enemy, covering his body with tiny poisonous bites. Nevertheless, whether the opposition was drastic or subtle, De Kom's message is clear: marronage served a serious cause, demonstrated an intrinsic need for freedom characteristic of mankind and in that sense foreshadowed modern anticolonialism. Its actual relevance, however, is largely symbolic. In Wij slaven van Suriname De Kom in no way wishes to imply that contemporary Surinamers had to use military means to resist colonialism.

In the second part of Wij slaven van Suriname, entitled "The Era of Freedom," the Surinamese perspective includes the population groups composing society since the postemancipation decades. In addition to the attention he gives to the descendants of "negro slaves," De Kom in this section reports on the movements of East Indians (called Hindustanis in Suriname) and Javanese (originating from Indonesia, but not solely from Java), who had entered Suriname as indentured laborers and who after their contract had expired tried to make a living in their new homeland, as a rule in subsistence farming and the production of foodstuffs for the local market.

Long before Tinker (1974) classified indentured labor "a new system of slavery," De Kom devised a "slave" category in which he incorporated slaves, indentured laborers, and their descendants. It is this extended category he is referring to in the title of his magnum opus. ${ }^{11}$ In his opinion not only the "negro" population had suffered on the plantations, but their successors had

11. Present-day intellectuals relatively often emphasize the importance of Wij slaven van Suriname as a source of information on the Afro-Surinamese population group (Van Stipriaan et al. 2007:129-30) or, ideologically speaking, as a precursor of Black Power in Suriname (Helman 1995:31). This demonstrates not only the variety of interpretations the 
also endured (and in the case of the Javanese, still endured) the hardship of exploitation and degeneration, notwithstanding the human traits these workers were given and the rights they enjoyed according to official regulations. De Kom held the view that not the ethnic differences between the Surinamese population groups, but their similarities in social status and economic wellbeing had to be considered a key element in creating a Surinamese society free of exploitation and subordination. ${ }^{12}$

\section{RECONSTRUCTION OF SURINAMESE SOCIETY}

Because "The era of freedom" deals with contemporary issues and developments, its emphasis is on politics rather than on history. In this second section De Kom shows his familiarity with the work of the nineteenth-century Dutch author Multatuli (pseudonym for Eduard Douwes Dekker), who, building on colonial service experiences in Indonesia, had severely criticized forced labor and the exploitation of the Javanese in his famous novel Max Havelaar (1860), but who later had also rejected free labor, branding it a system prone to abuse and maltreatment as well. In Suriname, De Kom asserted, free laborers had much in common with their "comrades" in the eastern part of the Dutch colonial empire. In both regions feelings of humiliation and distress were prevalent among working-class people. ${ }^{13}$

This was particularly evident in the 1930s. In response to the world economic crisis, the Dutch government launched a strict austerity policy, while substantial actions directed at relieving the misery of the poor and jobless seemed equally appropriate. From the Netherlands, where he had been residing since 1921, mainly working as an accountant and a business agent, De Kom observed in particular the efforts of Louis Doedel, who since early 1931 had organized the unemployed and had negotiated with the colonial administration in Suriname to enforce labor reforms and create jobs. On 28 October 1931, a mass meeting of Doedel's Surinaamsche Volksbond (Surinamese People's Association, SVB) got out of hand and ended in a hunger revolt. Police forces were called in to restore order. Their clashes with the raging crowd resulted in one dead, two wounded, and 56 arrests. To De Kom "red

text of Wij slaven van Suriname allows for, but also the different meanings contemporary readers attach to the book.

12. Oostindie argues that De Kom attempted to "write away" the ethnic divisions distinctive of Surinamese society. I would say he at least underexposed and presumably also underestimated these differences, being too greatly absorbed by his endeavor to counterbalance the divide-and-rule strategies of the colonial government. See Oostindie 1990:6. 13. Multatuli's limited influence on Surinamese authors is discussed in Van Kempen 1998. On De Kom and Multatuli, see Van Kempen 1998:201-4. 
October" was a tragic extreme of colonial oppression, but also a promising manifestation of popular resistance.

Apart from the appalling reports he received about the effects of the economic crisis in his native country, De Kom's networks also served to inspire action. In fact, De Kom collaborated with three groups of like-minded people. Firstly, he was influenced by Indonesian students in the Netherlands, who prepared for their country to be liberated from Dutch colonial rule. Their principal association was the nationalist Perhimpoenan Indonesia, led in the 1920 s by Mohammed Hatta, future prime minister of the independent Republic of Indonesia. In addition, De Kom cooperated closely with Dutch organizations promoting (openly or covertly) communist ideals, such as the Liga tegen Imperialisme en voor Koloniale Onafhankelijkheid (League against Imperialism and in support of Colonial Independence) and the workers' and artists' collective Links Richten (Directing Left). In those days the Communistische Partij Holland (Dutch Communist Party, CPH) was the sole political party in the Netherlands to show a keen and positive interest in nationalist organizations in the Dutch colonies, and it assiduously urged the transfer of sovereignty to the colonized people. Finally, De Kom, since the early 1930s, maintained regular contacts with Surinamese working-class leaders, notably Louis Doedel and Theo de Sanders. ${ }^{14}$ Sailors employed with the Royal Dutch Steamboat Society acted as their couriers, passing on messages and distributing political writings. The local Surinamese labor leaders, who generally tended more toward the principles of the Dutch Sociaal Democratische Arbeiders Partij (Social Democratic Labor Party, SDAP), ${ }^{15}$ accommodated De Kom's return to Suriname in 1933.

De Kom's interlocking connections convinced him that lower-class AfroSurinamese, Hindustanis, and Javanese were all proletarians betrayed by the false promises of free labor and in need of an organization that could stand up against hardship and oppression:

We want to prove only one thing: colored fellow countrymen, you are slaves, you will remain living in poverty and misery, as long as you do not trust your own proletarian unity. We cannot be saved with an incidental plot of land, a spade or a plough provided on credit. A great plan of national reconstruction is needed, a plan directed at collective enterprises

14. Kinshasa $(2002: 42,46)$ - who does not provide ample evidence - believes that these relations went back to 1918, before De Kom left for the Netherlands.

15. In 1937, this political party - from its beginnings in 1894 an internationally oriented Marxist-based party and, as such, the most important moderate rival of the Dutch communist party - dropped class struggle from its political program and unconditionally adopted parliamentary democracy. From that moment on the SDAP presented itself as a national people's party. In 1939, for the first time, the SDAP accepted cabinet posts in the Dutch government. De Kom renounced the reformist stance of the SDAP. 
with modern equipment in the possession of the workers of Suriname. We will have to build up our welfare with our own hands. This plan requires a great effort from us as Surinamers. But firstly the proletarians in our country have to arrive at militant class-consciousness, firstly we have to shake off, together with the old slave chains, the old slave mentality. (De Kom 2003:164)

In the epilogue of Wij slaven van Suriname, "Reencounter and Goodbye," De Kom provided a brief account of his 1933 experiences as an activist leader in Suriname (see next paragraph), in which he included references to "the comradeship of the proletarians and their love of freedom" and in which he repeated his wish to pass on to his comrades

the hope and courage embedded in that powerful word I learned abroad: organization. Maybe I will succeed in erasing the divisions which have been the weak spot of these colored people, will it not be entirely impossible to let negroes and Hindustanis, Javanese and indigenous people understand that only solidarity can unite all sons of mother Sranan in their struggle for a human existence. (De Kom 2003:167, 169-70)

There is no mention of a "revolutionary takeover," "the dictatorship of the proletariat" or the establishment of a "classless society" in Wij slaven van Suriname. De Kom in his book also refrains from alluding to existing socialist models (for instance the one applied in the then Soviet Union) or to specific scenarios to put his ideals into effect. Apart from De Kom's inclination to focus on practical action rather than on terminological correctness or theoretical debate this apparent lack of ideological elaboration is to a great extent due to the stance of the Dutch authorities. They forced the author to keep a low profile and to comply with the interbellum political regime in the Netherlands, which condemned communism and excluded members of the Communistische Partij Holland from posts in government agencies. In his book De Kom explicitly states that he has not been nor is a member of the Dutch communist party (De Kom 2003:189). Although there is no irrefutable evidence about the reliability of De Kom's claim, it is safe to assume that his message partly served image-building purposes.

Many writers have pointed out that Wij slaven van Suriname was subject to censorship which brought about a number of changes in the original manuscript. The initial text being lost, investigations into the authenticity of the published work are difficult. However, prepublications of book fragments suggest the exclusion of several lines and paragraphs from the final version, such as the one on the prospects for liberation in Suriname when "great and conscious revolutionaries" like Baron, Boni, and Joli Coeur (well-known Maroon guerrilla leaders) would rise up once more. In the same passage 
Dutch proletarians were encouraged to appreciate "our freedom fighters" and to carry with them images of these leaders together with Lenin's portrait during their demonstrations on the day that the great liquidation of capitalism would take place. ${ }^{16}$ Whether a member of the Dutch communist party or not, this fragment indicates De Kom's adoption of at least portions of the communist ideology propagated in the Netherlands in the 1930s. ${ }^{17}$

It is commonly assumed that another testimony to De Kom's radicalism is the text of a pamphlet - also not included in Wij slaven van Suriname - that circulated in Suriname in early 1933 when De Kom was there. The program disclosed in this leaflet called for "national liberation, complete self-determination, constitutional independence, Suriname and Curaçao cut off from Holland now," "extermination of the privileges of foreign imperialists and nationalization of foreign concessions and plantations," "unlimited freedom of organization and press for workers, small farmers, Maroons and other oppressed people," "promotion of economic, political and cultural emancipation of the oppressed classes and races, and equal rights for man and woman" and "a unity organization for all workers and farmers and collaboration with the Dutch, Indonesian, Soviet and international movements" (Scholtens 1986:79-80). ${ }^{18}$ These sweeping demands, also expounded in a number of articles in the communist press, ${ }^{19}$ most likely reflect De Kom's ultimate political agenda. However, data being scarce, we also have to proceed carefully here. It is impossible to overlook or disregard speculation intermingling with information when dealing with this particular subject. ${ }^{20}$

16. Jansen van Galen 2003:8, Kagie 2006:171-74, Para 1989:105, 109-13, Scholtens 1986:80-81, Wijnen 1989:12, 16. See also National Archives, The Hague, Gouverneur van Suriname, Geheim Archief, 2.10.18, inv. no. 58, various documents.

17. Boots and Woortman hold the view that the key prepublication from which the quotations in this paragraph come most likely cannot be attributed to De Kom. One of their main arguments pertains to sources unused thus far. Reconstructing the genesis of Wij slaven van Suriname Boots and Woortman conclude that stylistic considerations on the part of the publisher rather than censorship methods applied by the metropolitan authorities underlay the many adjustments made to the initial manuscript of the book. In determining the authorship of the prepublication, however, these data can serve as circumstantial evidence only.

18. In 1910, Frans Pavel Killinger had voiced similar pro-independence demands, but because he failed to execute an intended coup d'état and because he was detained and expelled from Suriname, his ideas quickly faded from public memory.

19. Passages from De Kom's articles published in Links Richten, De Tribune, and De Communistische Gids are included in Oostindie 1986:66-76, Para 1989:91-130, and Scholtens 1989:13-19.

20. According to Boots and Woortman it is doubtful whether the pamphlet bears the signature of De Kom. Their useful assessment, however, does not exclude the possibility that De Kom subscribed to the views expressed in the text. 
De Kom's fixation on a reconstruction of Surinamese society was definitely Marxist-inspired, but to term the author a student of Marxism or a Marxist thinker would not do justice to the essentially performative roles he took as an activist and a writer. Basically the ideas he endorsed were marked by simplicity. De Kom assumed that the economic foundations of the social order conditioned European, Asian, and New World societies. He considered the doctrine derived from this principle a philosophical "readymade," which he eagerly adopted as his ideological compass and political code of conduct. But De Kom's class-based convictions were as much rooted in Marxist theory as in everyday life experiences and private encounters with people. His passionate appeals to do away with inequalities and injustices and his engaging attempts to improve the living conditions of the have-nots and ill-fated revealed a sensitive and intuitively applied Marxism, disconnected from political discourse and scholarly analysis. Some of his contemporaries rightly observed that De Kom fought the class struggle with his heart rather than with elaborate concepts or fixed dogmas in mind. ${ }^{21}$ Without question De Kom's drive was not targeted at the consideration, fleshing out, and sophistication of Marxist ideals, but at practical operations directed at egalitarianism and social justice. ${ }^{22}$

\section{STRONG PERSONAL ENGAGEMENT}

The hybridity of Wij slaven van Suriname, which bears traces both of a scholarly work and a political treatise, is further confirmed by De Kom's inclusion of scraps of autobiography throughout the text. Abiding by the socialist convention of submitting the personal to the collective, De Kom does not elaborate on his private experiences. Yet, the incorporation of personal interludes effectively allows the reader to identify with the fate of lower-class Surinamers. Furthermore, these anecdotes support and illuminate the more objective overall explanations the author puts forward.

The deficiencies in the school curricula, particularly the lack of serious attention for Surinamese history, inspired De Kom to write down some of his most personal memories. An exemplary quotation: "Better than in the history books of the white, the maltreatment of our fathers has been recorded in our own hearts; never has the agony of slavery spoken more intensely to me than

21. See documentary film Wij slaven van Suriname directed by Frank Zichem (1999).

22. In Johnson 1982 refined analytical tools are deployed to examine Marx's working method as well as his philosophical premises. It is tempting to apply these tools to Wij slaven van Suriname to accurately establish the Marxist influences in the book. However, since De Kom is rather implicit and evasive about the rationale underlying his work this exercise would not make sense. 
from the eyes of my grandmother when she told us children, in front of the cabin in Paramaribo, the tales of the old times" (De Kom 2003:46). Likewise, De Kom recalls the Maroon friends his father took home with him when he returned from the goldfields to the capital. The son, raised in a society that mimicked the prejudices of the colonial elite, shamefully admits that he and his schoolmates talked disdainfully about his father's guests, regarding themselves as superior to those whose language and way of life they could not understand. "Our contempt was one of the strongest links of the chain with which we were bound to the western production system. Only when the old slave mentality has disappeared from our hearts will the Surinamer come to human dignity" (De Kom 2003:80).23

It is the epilogue outlining De Kom's short-lived activist experiences in Suriname which stands out as the most intriguing piece of autobiography in Wij slaven van Suriname. Although many details concerning the 1933 events have remained obscure until today, the main story is clear. ${ }^{24}$ Late December 1932, De Kom traveled to Suriname, the first time since he had moved to the Netherlands. According to his commentary in Wij slaven van Suriname the chief motive for his return was his desire to visit his mother, who was gravely ill. Tragically, she died before he had reached his destination. But apparently De Kom intended to re-migrate altogether, since his wife, who was Dutch, and children, who were born in the Netherlands, accompanied him and so did many boxes of furniture. From the moment his feet touched Surinamese ground De Kom was shadowed by police officers. The authorities, alerted to his reputation as a "communist agitator," were concerned that he would seize the opportunity to stir up the masses and upset the political status quo.

Since De Kom was denied the right to organize meetings, he set up an "advisory and information bureau" in his parents' yard. He registered the names and addresses of the people who visited him and wrote down their

23. These words resemble Marcus Garvey's celebrated statement "Emancipate yourselves from mental slavery, none but ourselves can free our mind" (popularized by Bob Marley in "Redemption Song"). De Kom might have become acquainted with Garvey's thinking and actions in 1920, when, on his way to the Netherlands, he worked for two months with the Société Commerciale Hollandaise Transatlantique in Port-au-Prince, Haiti. Garvey and De Kom both championed the emancipation of the lower strata in their societies, Garvey primarily on the basis of race, De Kom on the basis of class. Although his small oeuvre does not include explicit comments on Garvey, it is worth mentioning that De Kom (2003:25) admired the Dutch translation of Magdeleine Paz's account of black emancipation in the United States. In this work, which was widely read at the time of publication, the author (Paz 1933:199-205) firmly rejects Garveyism as unfeasible and utopian, and stresses the need for crosscultural and multiracial collaboration in a unified labor movement. See also Kinshasa 2002:43-44.

24. Mainly derived from Hira 1982:296-321, Hoefte 1998:180-85, Van Lier 1971:36878 and Scholtens 1986:74-90, 137-54. 
complaints. Hundreds of people made their way to De Kom's temporary residence, particularly those of Javanese and Hindustani descent who lived in the rural districts. They were attracted by the prospect of De Kom's providing them with a free passage to Java or India. Because of the deplorable material and social circumstances in which they lived and their apparent lack of education they attributed mythical powers to De Kom, considering him a kinglike figure, a messiah, an incarnation of Gusti Amat (a legendary nineteenth-century prince who had been expelled from Java to Ambon and who was believed to have come to Suriname to save his people) and a disciple and representative of Gandhi. There is still dispute as to whether De Kom deliberately misled his followers, misusing his charisma and creating expectations he could not meet. Some important sources, however, assert that opponents of De Kom spread false rumors to discredit and outrival him. They are convinced that these adversaries deceitfully claimed that De Kom collected money from immigrants supposedly as a payment in advance for their repatriation, but basically to fill his own pockets. Unfortunately a shortage of factual testimony also precludes significant conclusions here (Breunissen 2001:17-21, 170-71, Verheij \& Van Westerloo 1984:35, Wicart 1990:86). ${ }^{25}$

On February 1, 1933, the authorities prohibited De Kom's organizing a meeting near his parents' home. This refusal, which he considered unfair, taking into account the needs of the people and the opportunity he had created to act as their solicitor, induced De Kom to go to the governor to protest. A large crowd of people followed him. That day the governor was unable to receive, officially for medical reasons. Thus De Kom dissociated himself from his supporters and accepted an offer to go by car to the police station. He was told that there, in place of the governor he could meet the attorneygeneral. However, at the location of the meeting police officials arrested him. His adherents, who in the meantime had tracked down De Kom and had rallied in front of the police station, were violently dispersed.

The following days the city of Paramaribo remained restless. There were riots and pleas to release De Kom which were rejected by the attorneygeneral on the ground that evidence had been found that De Kom had serious plans to overthrow the government. Despite his assurance that De Kom would remain in prison and even though public gatherings were prohibited, on February 4 the rumor that De Kom would be set free on February 7 rapidly spread and created great excitement. On that day a huge crowd, including vast numbers of Javanese, assembled on the main town square opposite

25. The longing for a charismatic guide and savior, capable of leading them out of their misery into a refuge resembling a promised land, has occupied the minds of the Javanese ever since the times of De Kom. Leading Surinamese-Javanese politicians willing to adopt the savior role were, in succession, Iding Soemita, Willy Soemita, and Paul Salam Somohardjo. 
the governor's palace and nearby Fort Zeelandia where De Kom was being detained in anticipation of his release. But instead of being allowed to reunite with their leader, the police cleaned the square, whereupon the people proceeded to the office of the attorney-general. They pushed their way forward attempting to break the police cordon guarding the building. The angry mass of people, determined to enforce the return of their leader and unwilling to obey orders to retreat, threatened and ridiculed the police officers, who at one point started to fire at the crowd. In the subsequent confrontation two demonstrators were killed and twenty-three injured. De Kom was expelled from the colony on May 10, after three-and-a-half months of detention, without a trial. Later the authorities acknowledged that there was insufficient proof to convict De Kom.

De Kom's four-and-a-half month stay in Suriname, during which he effectively worked as an activist for only one month, ${ }^{26}$ prompted the authorities to announce anti-revolution laws, to improve the arms of the police forces, and to establish a citizens' guard. These decisions practically silenced the actions of the Surinamese labor leaders in the remaining decade. Back in the Netherlands De Kom completed Wij slaven van Suriname, ending his work in calm anxiety: "Sranan my fatherland. One time I hope to see you again. On the day that all sorrow will be removed" (De Kom 2003:179). ${ }^{27}$ De Kom, however, would never return to Sranan.

His confidence in the spirit of progress unshaken, De Kom continued activist work in the Netherlands, but as a political exile he had great difficulties making a living. Basically he was unemployed and dependent on social welfare. Temporary, low-status jobs generated some irregular income. During the Second World War, De Kom joined the communist branch of the Dutch resistance movement against the Nazi occupier, remaining faithful to his ideals and consistent in his engagement with subordinate people, whether it was the Surinamese colonized or the Dutch colonizer. Betrayed in 1944, De Kom was imprisoned by the Nazis and deported to Germany. In early 1945 , having suffered severe hardships in a number of concentration

26. Historians Ben Scholtens and Hans Ramsoedh brought forward this fact to articulate that the importance of De Kom as a Surinamese labor leader has been seriously overrated as compared to that of Doedel. See Scholtens 1987:5, 25 and Brautigam 1999:25-29.

27. A claim by Jef Last (1898-1972), one of De Kom's political associates, that he was actually the author of Wij slaven van Suriname was proven false. Last, however, did provide De Kom with editorial assistance. See Van Kempen 2003a:602, Oostindie, 2008, "Kom, Cornelis Gerhard Anton de (1898-1945), "Biografisch woordenboek van Nederland, http://www.inghist.nl/Onderzoek/Projecten/BWN/lemmata/bwn5/kom and Van Suchtelen, 2003, "Kom, Cornelis Gerhard Anton de," Biografisch woordenboek van het socialisme en de arbeidersbeweging in Nederland, http://www.iisg.nl/bwsa/bios/kom. html. 
camps, De Kom died in camp Sandbostel, an annex to concentration camp Neuengamme.

In 1933, did De Kom return to Suriname on an assignment of the Dutch communist party? He may have, given his political connections and ideals. Yet there is no hard evidence supporting this assumption. Did De Kom wish to bring about a revolution in his native country? Obviously he wished to improve the living conditions of the lower-class people and to boost their fighting spirit and motivation to resist the colonial government. However, there is reliable testimony that in 1933 De Kom judged that Suriname was unprepared for revolution and on principle rejected the use of violence. This indicates that an immediate takeover of power in Suriname was not part of his program (De Kom 2003:168-70, 173-75). Moreover, for practical reasons De Kom preferred to behave as much as possible in accordance with the rules of the game set by the colonial authorities. This is why he confined himself to nonviolent methods of action such as mass mobilization and propaganda. Most likely De Kom's activities in 1933 were meant to be the initial stage of a trajectory directed at setting up a large and stalwart labor organization that would give Surinamese workers substantial political power.

Why were so many Javanese and to a lesser extent Hindustanis attracted to De Kom's ideals? Several explanations have been given. The fact that both groups were largely neglected by the colonial government compared with the Afro-Surinamese group and that they harbored deep feelings of nostalgia for their homeland seems to have made these workers more receptive to the acts and speeches of what they considered a messianic leader. Besides, the Afro-Surinamese already had their workers' organizations, but were discouraged by the meager results of their leaders, particularly following the 1931 hunger revolt. Furthermore, they presumably had their reservations about De Kom because of his radicalism and the nimbus of authority and pedantry that seemingly surrounded him. Finally, De Kom's focus on the Javanese and Hindustani workers seems to have been a matter of tactics and labor division as well. Leaving the Afro-Surinamese proletarians to fellow leaders like Doedel, De Kom, in addressing the main Asian groups, could foster his credibility as a bringer of an ethnically neutral, class-centered message. The fact that he was accustomed to associating with people of Indonesian descent probably served as an asset.

Particularly the active support of the Javanese for De Kom did alarm the authorities. Throughout the 1930s and 1940s the fear of a repeat of the 1933 disturbances - taking into account the interest many Javanese took in operations of the nationalist movement in Indonesia, the charisma of nationalist leader Sukarno, and the proclamation of independence in Indonesia in 1945 - kept the colonial administration alert and motivated them to let intelligence 
services observe the movements of the Javanese population closely. ${ }^{28}$ Unlike the developments in the English-speaking Caribbean, where labor unrest peaked in the late 1930s, in Suriname following the expulsion of De Kom social and political disquiet was successfully curbed by the colonial government which strictly adhered to the anti-revolution laws ("muzzle decrees" as they were commonly referred to) and the established authoritarian way of dealing with undesirable opposition.

\section{COMPARISON WITH WILLIAMS AND JAMES}

Wij slaven van Suriname, Eric Williams's Capitalism and Slavery, and C.L.R. James's The Black Jacobins show definite similarities in aim, approach, and argumentation. ${ }^{29}$ Their common points can be classed under the headings "emancipation," "race and class consciousness," "identity politics," and "nationalism." The works center on Caribbean people and their struggle for liberation, self-respect, and dignity. As for their approach and analysis the authors rely on scholarly methods and literary techniques and offer a compelling line of reasoning directed at the creation of a new perspective on Caribbean history. Taking a decisive stand on ideological matters, the books reflect the spirit of interbellum Europe, which gave birth to fascism and communism as opposing political systems uncompromisingly aspiring for world hegemony.

At the same time the three works under discussion differ in ambition and scope. Besides divergences in their talent and aspirations, the authors also have diverse educational backgrounds. Eric Williams and C.L.R. James had ranked among the most talented pupils of their generation at Queen's Royal College, Port-of-Spain, Trinidad. His brilliant performance at Queen's had resulted in Williams's being awarded an Island Scholarship to advance a

28. Gouverneur van Suriname, Geheim Archief, 2.10.18, inv. no. 47, 53, 54, 55, 522, 524, 527, 538, 578, National Archives, The Hague. Simon Sanches, in 1947 instigator of a coup d'état that was prematurely betrayed by one of his fellow conspirators, considered the Afro-Surinamese and the Javanese the only population groups that stood to benefit from his planned takeover. A statue in honor of De Kom was part of his unrealized plans.

29. Broached in Meel 2001:228. In his brief review of these important studies Oostindie (2004:498-99) also includes Aimé Césaire's Cahier d'un retour au pays natal. But it being a work of poetry, I consider it less self-evident to incorporate this book into the comparison presented here. Despite obvious similarities with Wij slaven van Suriname I also exclude Léon Damas's Retour de Guyane, the principle reason being the obscurity of this work in historiographical and political debates in the Francophone Caribbean and beyond. 
university study in the United Kingdom. Having obtained a doctoral degree at Oxford University, Williams would embark on an extraordinary career, successfully pursuing scholarly and political goals. He built up a solid reputation as a Caribbean historian and would serve nineteen years as the prime minister of Trinidad and Tobago. James determinedly chose not to attend university, but to lead the life of an independent artist and revolutionary. Notably as a writer and journalist he demonstrated a zeal for contemporary issues connected with Africa and the Caribbean, critically examining the theoretical foundations and practical implications of self-governance, independence, Pan-Africanism, Marxism, and Trotskyism. James's intellectual legacy is abundant, ranging from prose fiction and literary criticism to writings on politics, history, and sports (cricket).

Set against these exceptionally gifted and energetic characters, De Kom's credentials turn out to be modest. Having finished the Roman Catholic Paulus School in Paramaribo, a type of school offering lower general secondary education, at that time the highest level of education one could get in the colony, De Kom took private courses in bookkeeping and accountancy. In the Netherlands, as a consequence of his low birth, corresponding financial constraints, and the unavailability of scholarships, he could not continue his studies on a regular basis. Instead, as an autodidact he trained himself to read scholarly books, discussing political issues and developing a way of thinking bearing the mark of substance and authenticity.

Apart from the absence of formal higher education experiences and qualifications, which forced him to find out things primarily by himself, De Kom had the bad luck of being raised in a colony and later living in a mother country of an empire that did not play a major role in world politics and was known for its rather inward-looking and complacent way of life. This affected the curricula Dutch students were offered and the intellectual makeup and level of ambition society required from its citizens. The schooling in the British educational system, which paid equal attention to knowledge acquisition and the development of analytical, creative, and oratory skills, together with the emphasis laid on the mastery of the English language and the cultivation of a mentality directed at competition and fair play, contributed to a more comprehensive intellectual basis and a more international orientation to the advantage of those who were eager to exploit their talents. No doubt Williams and James were among those who in their work made the most of their education. In this respect De Kom lagged behind.

What are the three books by these authors about? In Capitalism and Slavery Williams vigorously explains that the slave trade and "negro slavery" were the core constituents of eighteenth-century commercial capitalism, which provided capital to finance the Industrial Revolution. Moreover, the author challenges the view that the termination of the slave trade and slavery were primarily the triumph of British humanitarianism, according to him 
"one of the greatest propaganda movements of all time" (Williams 1994:178). Williams argues that instead the abolition of both institutions was a consequence of the development of nineteenth-century industrial capitalism, which led to the emergence of new manufacturing and industrial classes in Britain. These classes considered the maintenance of the West Indian monopoly and slavery incompatible with their economic interests; this would impede the making of profit. Despite Williams's conviction that there does not exist a strict line of demarcation between historical and political judgment and that the roles of the historian and the politician cannot be adequately separated, Capitalism and Slavery is a scholarly work, to be more precise an economic study that has been the object of intense academic debate for sixty-five years now. As such it is a marked contribution to Caribbean scholarship. ${ }^{30}$

James in The Black Jacobins eloquently relates the complex story of the Haitian Revolution with special reference to the role played by its principal leader Toussaint L'Ouverture. His book is a stirring narrative of rare literary refinement, firmly grounded in the available primary sources. Appropriating a Marxist paradigm, James elucidates the nature of Caribbean society, pointing to the predominance of race and class ${ }^{31}$ and depicting slaves as "closer to a modern proletariat than any group of workers in existence at the time" (James 1989:86). Illuminating the contribution slavery made to the development of the modern world, James laid the basis for the Williams thesis (James 1989:51-54, Williams 1994:268).

A theoretical issue James embarks upon in The Black Jacobins is the relationship between societal forces and the impact of leading personalities like L'Ouverture in bringing off a revolution. The question of whether the revolution made Toussaint or Toussaint the revolution prompts James to take a middle position, however, adhering to historical determinism: "Great men make history, but only such history as it is possible for them to make. Their freedom of achievement is limited by the necessities of their environment" (James 1989:ix, 91). In the end, James indicates, human agency is determined by material context. ${ }^{32}$

30. Also compare Benn 2004:80-85. Solow \& Engerman 1987 is a collection of specialist responses to the key arguments set out in Capitalism and Slavery.

31. Epitomized in James's well-known aphorism: "The race question is subsidiary to the class question in politics, and to think of imperialism in terms of race is disastrous. But to neglect the racial factor as merely incidental [is] an error only less grave than to make it fundamental." See James 1989:283.

32. It is difficult to assess whether James considered this a matter of rhetoric rather than of principle. Meeks (1996) discloses that the cultural and psychological explanations that James puts forward in the portrayal of Toussaint and Dessalines demonstrate that individuals do have room to act independently and autonomously, a line of argument that cannot be accommodated comfortably with Marxist orthodoxy. 
In The Black Jacobins the role of the masses is another topic that receives ample attention. According to James, the French masses were a major factor in the success of the Haitian Revolution. In the Jacobin days, they had persuaded the National Convention to abolish slavery in all French colonies and to declare all men French citizens with equal rights. This decree, passed in early 1794, impelled L'Ouverture to pursue one of his most victorious military campaigns, which would eventually save the revolution (James 1989:137-44). To James, the interconnectedness of the French and the SaintDomingue revolutions predominantly reflected international proletarian solidarity. The Paris masses had triumphantly demonstrated their support for the liberation struggle of their overseas compatriots. This "instinctive internationalism" of the working class, in James's opinion, had to be the foundation of the "permanent revolution," one of the credos of Trotskyism (Benn 2004:156-60).

In The Black Jacobins the Haitian Revolution serves as an example for communities on the brink of decolonization. According to the author the capacity of the Saint-Domingue slaves to defeat the most powerful European nations at the turn of the eighteenth century, to transform society and create an independent black state demonstrated the African people's capability of self-government. James had written The Black Jacobins with Africa in mind as a result of his collaboration in the late 1930s with George Padmore, the then leading black communist and Pan-Africanist. Both actively participated in the management of the International African Service Bureau (IASB), which supported the democratic rights and liberties of African people. In 1963, James would add an appendix to The Black Jacobins, linking Toussaint L'Ouverture to Fidel Castro and acknowledging the importance of relating Caribbean history to developments within the region itself (James 1989:391418).

Wij slaven van Suriname is not a scholarly achievement, although it bears some of the characteristics of a historical work, such as the use of primary and secondary sources and the employment of a Surinamese perspective. Yet De Kom never intended to address academia nor had as his prime motive to add to the existing body of scholarly literature on Suriname. It would therefore be beside the point to place Wij slaven of Suriname in the same category as Capitalism and Slavery, which was the elaboration of a $\mathrm{PhD}$ thesis defended in 1938 and was explicitly written to challenge and impress an academic audience. Owing to the efforts of historians, Wij slaven of Suriname continues to be included in scholarly debates, while the author himself never had these intentions. This remains a major source of confusion about De Kom's book.

Neither can Wij slaven van Suriname satisfactorily be labeled a work of art and revolution if we compare it to The Black Jacobins. Admittedly, De Kom's book is written in a most accurate and moving style and touches 
on a number of significant ideological questions. Moreover, the author presumably ${ }^{33}$ would have agreed with James on a number of issues such as his findings on race and class, the historical role of revolutionary leaders, and international proletarian solidarity (except for the Trotskyist twist he would probably have objected to). From these points of view Wij slaven van Suriname is more akin to The Black Jacobins than to Capitalism and Slavery. However, De Kom, in comparison with James, is not as adept at dealing with theory. In fact, his references to concepts and principles (mainly Marxist ones) are scarce and his corresponding reflections lack depth and sophistication (Scholtens 1986:81). ${ }^{34}$

Finally we have to take into account that Capitalism and Slavery and The Black Jacobins do not display the strong personal engagement of Wij slaven van Suriname. Both James and Williams in their books refrain from letting private experiences interfere with the subject matter they examine. Differently from De Kom they consciously exclude references to autobiography and personal memory and stick to historical facts and scholarly argumentation as much as possible. Obviously for Williams this was part and parcel of the academic standards he as a PhD student had to meet. Most likely James made his choice on artistic as well as ideological grounds. Selfconfidently drawing upon a variety of historical sources, theoretical presuppositions, and literary strategies, he shunned allusions to episodes and events that could distract from the "grand narrative" he wished to write.

The accuser's role De Kom adopted in Wij slaven van Suriname, the employment of a Surinamese perspective, the belief in a reconstruction of Surinamese society, and particularly the display of a strong personal engagement give his book the characteristics of a powerful political essay. De Kom wrote it to inspire, instruct, and encourage people to resist colonialism and to aim for national unity and social justice. Articulately written and containing many poignant anecdotes the text was meant to persuade its readers to embrace enlightened ideals and urge them to take action in concerted fashion. ${ }^{35}$ However, due to enduring colonial repression Wij slaven van Suriname

33. Although this will remain a matter of speculation we have to assume that De Kom never read Capitalism and Slavery nor The Black Jacobins.

34. Hira (1982:vii-viii) aspires to make up for what he deems to be De Kom's scholarly and theoretical deficiencies.

35. Interestingly Van Kempen (2003a:600-1), persuasively highlighting the essayical features of the book, poses the question of whether De Kom, in writing Wij slaven van Suriname, intended to produce a work of literature on account of the many lyrical descriptions he inserted in the text (see also note 7). This fundamental question, which resembles attempts to label Karl Marx's Das Kapital a work of art (Wheen 2006:74-81), still awaits further examination. In my view De Kom was too much of a political activist to justify this assumption. He primarily considered his artistic gifts instruments to attain his socio- 
remained underground for a considerable period. In Suriname it was only within a small circle of trade unionists and nationalists that its content was talked about. 36

Following various clandestine editions and the 1971 official reprint of Wij slaven van Suriname the humanity of De Kom's message and the integrity of his actions increasingly met with favorable reactions. The rediscovery of his book, together with wide publicity given to the author's life of engagement and sacrifice, awakened a new generation of Surinamese students and encouraged them to adopt class-based views and to dissociate themselves from the ethnic stand of the established political parties. De Kom was posthumously heralded as a forerunner of Surinamese nationalism and commonly adopted as a symbol of anticolonial resistance. ${ }^{37}$ Consequently Wij slaven van Suriname became instrumental in stimulating debate on independence and social justice. It was the newly established Volkspartij (Peoples' Party) and the Progressieve Arbeiders en Landbouwers Unie (Progressive Workers and Agrarians Union, PALU) - more than the Partij van de Nationalistische Republiek (Party of the Nationalistic Republic, PNR) which had existed since 1961 - which considered themselves the keepers and torchbearers of De Kom's ideological legacy. However, both the Volkspartij and the PALU performed disappointingly in the parliamentary elections. In the 1970s they did not obtain a single seat in the Surinamese legislature.

Following the military takeover of 1980 , representatives of a radical splinter group of the Peoples' Party, named the Revolutionaire Volkspartij

political goals. Consider also De Kom's posthumously published collection of poetry (1969).

36. Nationalist leader Eddy Bruma was one of the few Surinamese politicians of his generation who was demonstrably inspired by Wij slaven van Suriname. See Meel 1999:22326 and Marshall 2003:23-24.

37. Otto Huiswoud (1893-1961), another illustrious Surinamer who identified with the black working class, did not appeal to this politically ambitious age group. In 1910, at the age of sixteen, the Surinamese-born Huiswoud emigrated to the United States, where he became one of the founding fathers of the U.S. Communist Party. An energetic organizer and accomplished networker, he built up an impressive record as a unionist, journalist, and agent, every inch a loyal contributor to the Communist International. Upon his first return to Suriname after his emigration, in 1941, he was arrested on the charge of communist agitation and kept imprisoned for nineteen months. In 1947 he moved to the Netherlands, where as a senior activist he held leading offices in the Surinamese nationalist movement, but lived in poor material conditions until his death. Although there are striking parallels between De Kom and Huiswoud - both blended nationalist and internationalist stances and fought for the well-being of their fellow countrymen - the latter did not publish a book, was a victim of American anticommunism rather than of Dutch colonialism, and did not suffer from the barbarity of the Nazis. On Huiswoud, see Van Enckevort 2000 and Moore Turner 2005. 
(Revolutionary Peoples' Party, RVP) and delegates of the PALU gained powerful positions in the Surinamese administration. It was on their initiative that De Kom was proclaimed a national hero by the military leadership who were increasingly harshly authoritarian. A tragic fate befell De Kom: never before was his inheritance publicly fostered and cultivated with such vigor, yet the intentions of his promoters were radically different from the ideals of the example they so admired. In search of a justification for their coup d'état, subsequent armed repression, human rights violations, and "antiapanjath utopianism" (Dew 1993:67), 38 the military paradoxically turned to an advocate of nonviolent resistance and an opponent of totalitarian control.

From these years on, but also after the restoration of parliamentary democracy in 1987, the image of De Kom was fixed in statues, his name linked to streets and squares, his life and works publicized in articles, books, and documentary films, both in Suriname and in the Netherlands. To date, the Nationale Democratische Partij (National Democratic Party, NDP), the civilian successor to a military-led mass movement in existence before 1987 which was chaired by the former commander of the Surinamese army, Desi Bouterse, has always declared itself the heir to De Kom's ideas, notably those on nationalism, which according to the NDP are of an anticolonial and anti-ethnic nature. The anticolonial and multi-ethnic version of this nationalism particularly has supporters within the ranks of the Nieuw Front voor Democratie en Ontwikkeling (New Front for Democracy and Development, NWFO), a grand coalition of "old" political parties prominent before 1980. After 1987, these parties have ruled together, except for an NDP interlude between 1996 and 2000. In Front circles De Kom is well respected but unquestionably lacks the hero status he enjoys in the echelons of the NDP (Blanksma 2008:129-34).

\section{READING MEANINGFULLY}

According to David Scott a substantial number of works propagating anticolonialism manifest a distinctive narrative form: that of Romance. They are narratives of overcoming and vindication. Not only do they emphasize the glory of salvation and redemption, they also outline a utopian horizon toward which the emancipationist history is imagined to be moving. Over the

38. Apanjath refers to "the practice of ethnically based political parties playing upon prejudice, fear, and/or communal interests to gain support" (Dew 1993:65). The military set out to implement nationalist ideology in order to transcend ethnic parochialism. Primarily due to their Uzi-controlled absolutism they failed to connect with the interests and aspirations of the majority of the population. 
years the story-form of Romance 39 increasingly seems to have lost meaning. Undeniably in many former colonies the contemporary sociopolitical and socioeconomic configuration is radically at odds with the notions and expectations put forward by anticolonial intellectuals in previous decades.

Scott (2004:209-10) asserts that "after Bandung" 40 people's sense of time and prospects has altered significantly. There is no longer stable ground to consider the present a "mere transitory moment in an assured momentum from a wounded past to a future of salvation." As anticolonial utopias in many societies have withered into postcolonial nightmares, "the mythos of Romance," which celebrates "the epic momentum of successive historical events, the metaphysical movement from Darkness to Light, Bondage to Freedom, Despair to Triumph" (Scott 2004:70, 166), has unequivocally become obsolete. For Scott this ascertainment gives rise to an important question: how can we meaningfully deal with anticolonial works whose assumptions and predictions have failed to materialize?

A conscientious reading of C.L.R. James's 1963 edition of The Black Jacobins leads Scott to distinguish a second narrative form: that of tragedy. $\mathrm{He}$ contends that this narrative enables scholars to reflect scrupulously upon subjectivity in moments of historical crisis, for instance Toussaint L'Ouverture's ambivalent stand toward France during a crucial phase of the Haitian Revolution. His main argument is that for Toussaint, who denounced slavery, as well as a Saint-Domingue without France, modernity was a tragic condition, not a choice. It was a reality to which he was condemned and to which there were only tragic alternatives. In Scott's opinion Toussaint, whose hesitancy and irresolution are considered to have eventually propelled his exile and early death in France, embodies the tragedy of colonial modernity, that is, the paradox, enigma, and illusiveness of colonial enlightenment.

Scott postulates that endorsing a tragic vision of freedom means questioning the teleological unfolding of history toward a determinate end, but also a history governed by a sovereign and omnisciently rational agent.

39. In an earlier study Scott dubbed this story-form the "Fanonian narrative of liberation" involving projects of anti-imperialist self-determination, political and economic nonalignment, and varieties of socialism aimed at the termination of colonial subordination and tutelage (see Scott 1999:197-208).

40. In Scott's view (1999:221) "Bandung" represents "an historical form of the nationstatehood problematic that emerged as an ideological and political project with the nationalist movements for political independence across South Asia, Africa, and the Caribbean in the 1930s, 1940s and 1950s, and for which the great conference at Bandung, Indonesia, in April 1955, is iconic." "After Bandung," in the opinion of the author, largely converges with the end of the Cold War and the subsequent transformation of political relations from a bipolar into a unipolar world order under U.S. leadership. With respect to Jamaica, Scott (1999:196, 211, 221, 223) distinguishes different "After Bandung" moments. 
For tragedy, history is not leading us anywhere in particular. And if the past is a wound, it is one that may not heal; it cannot be evaded or cleanly overcome. It doesn't go away by an act of heroic agency. Nor is there a rational calculus that will guarantee the navigation of the contingencies that inevitably appear in the tragic hero's path. History, in short, is not a series of neat resolutions; the future does not grow triumphantly out of the wicked turmoil of the past. (Scott 2004:166)

Alternatively, the narrative form of tragedy honors the contingent, paradoxical, unexpected, illogical, and unyielding in human affairs. Reading anticolonial stories as tragedies of colonial enlightenment and as humanity's struggles with the contingencies hampering social organization and nation creation offers elements of a critical view of the colonial past as well as of the postcolonial present. Tragedy implies the acknowledgment of the limitations of the human mind and the incompleteness of human action, but also the existence of a legacy that requires continuous renegotiation and readjustment in order to mold a viable future.

Relating Wij slaven van Suriname to the narrative forms of Romance and tragedy we can begin by affirming that De Kom's work bears features of a story of vindication in that it addresses the accomplishments and capabilities of people neglected and treated as inferior for a considerable period. Reversing intellectual conventions, the author brings these individuals to the forefront of history and incorporates their thoughts, aspirations, and acts in the framework of their prolonged struggle for emancipation and justice. De Kom promotes a reconstruction of Surinamese society along the lines of class-consciousness, proletarian unity, and human solidarity, cautiously suggesting the redemption of his people to be the final stop on the one-way road to freedom.

Yet, despite this trust in a predestined future the tone and plot in Wij slaven van Suriname are neither victorious nor triumphant. The writer does not explicitly announce the demise of capitalism or the inescapable vanishing of colonialism. Nor can the reader - as might be expected in a work displaying the narrative form of Romance - trace corresponding predictions or anticipations presented in the form of a preponderant mantra, an "iron law," or an alternative token of historical inevitability. At the same time it cannot be denied that De Kom longed for the dissolution of the then hegemonic world system. He assumed that this would pave the way for the "era of freedom." But we deduce this particularly from supplementary sources, not so much from Wij slaven van Suriname itself. Summing up, we can infer that De Kom's seminal work exposes traits of the narrative form of Romance, but only when we relate its core ideas to complementary documentary evidence.

Not unlike The Black Jacobins, however, Wij slaven van Suriname also contains elements of the narrative form of tragedy. In general this pertains 
to the sad and dramatic history of the Surinamese people as delineated by the author. But more specifically, tragedy controlled De Kom's personal life. If we focus on his activist career the epilogue of Wij slaven van Suriname is most telling. It accentuates De Kom's failure to lay the foundations of a powerful labor organization in Suriname and to force the Dutch to take initiatives aiming at their retreat from the colony. In this sober tale of misfortune and distress the constraints are highlighted De Kom had to deal with. The final paragraph in particular moves the reader since he, contrary to the author at the time of writing, knows that De Kom's ardent wish to return to his native country was in vain. He would never be offered a second chance to visit Suriname and take part in a remodeling of its society.

On the level of migrant experiences - not an inherent part of Wij slaven van Suriname, but an important biographical layer underlying it - we observe that the contingent and unexpected definitely entered De Kom's life following his decision to move to the Netherlands in 1920. Most likely he wanted to extend his intellectual horizon and raise his standard of living. His arrival in the Netherlands marked the beginning of an onerous and sometimes outright confusing stay..$^{41}$ Before World War II there were only few Surinamers of lower-class origins residing in the Netherlands. To perform as a political activist and make a living De Kom needed to accept jobs as a clerk, a bookkeeper, and a business agent. After his expulsion from Suriname he increasingly had to protect himself from the onslaught of political and racial prejudice, and he was cut off from regular means of subsistence. His overseas stay took another significant turn during the Nazi occupation of the Netherlands, when he resolved to join the Dutch resistance movement against the German oppressor. Notably this decision would seal his tragic fate. ${ }^{42}$

If we spotlight the theme of modernity we have to acknowledge that for De Kom modernity was a condition (as it was for the majority of his contemporaries) and a choice (he embraced ideals represented by Enlightenmentinspired philosophers like Marx and Engels). In Wij slaven van Suriname the tragedy of colonial enlightenment is chiefly manifest in De Kom's commitment to class allegiance and his underestimation of the impact of ethnic cleavages on power relations. This stance, however, not only characterized De Kom, but the early pre-independence Caribbean Left in general (Mars 2003:68). There is some irony in De Kom's association with this movement though. Mainly because of its lack of dated elaborations on basic beliefs Wij slaven van Suriname, like The Black Jacobins, is still as captivating, appealing, and thought-provoking today as it must have been seventy-five years ago.

41. Perceptively discussed in the documentary film Wij slaven van Suriname.

42. De Kom as a transnational hero is examined in Meel 2008:257-61. 


\section{CONCLUSION}

Wij slaven van Suriname is an imaginative and persuasive work on resistance and a true specimen of "the empire writes back." De Kom wrote it with two goals in mind: to denounce Dutch colonialism using historical sources and private experiences as references and to awaken his fellow countrymen to begin decolonization and nation building. He wished to impress on his metropolitan audience the wrongs imposed by the colonial authorities in Suriname and the prolonged effects of their rule on the mental predisposition of the colonized. To his Surinamese contemporaries, particularly to his political associates, he wanted to convey a message of hope and solidarity and to provide the ideological tools to establish a new society.

De Kom was a nationalist in the sense that he advocated political independence and economic self-reliance for Suriname. At the same time, he was an internationalist, favoring class allegiance, proletarian solidarity, and the crushing of imperialism across states and nations. Before De Kom both the nationalist and the internationalist option had not been dealt with seriously by a Surinamese author, activist, or politician. Accordingly, De Kom has to be linked with the formative phase of Surinamese decolonization. In his book he connects the contestation of the existing colonial model to the prudent opening up of postcolonial avenues.

Comparing Wij slaven van Suriname to Capitalism and Slavery and The Black Jacobins demonstrates, in particular, the uniqueness of De Kom's forceful political essay. As a writer on Caribbean history De Kom is simply outclassed by Eric Williams and as a revolutionary and a man of letters he is no match for C.L.R. James. However, these qualifications too easily disregard the author's intentions and unjustly obscure the complexity and versatility of this work. It is the combination of the accuser's role De Kom adopted, the employment of a Surinamese perspective, the belief in a reconstruction of Surinamese society, and the display of a strong personal engagement that sets Wij slaven van Suriname apart from the classics produced by Williams and James. These features give the book its irrefutable significance, for Surinamese and Caribbean studies.

\section{REFERENCES}

BENN, DENIS, 2004. The Caribbean: An Intellectual History 1774-2003. Kingston: Ian Randle Publishers.

BLANKSMA, ANNE, 2008. De koek en de kruimels: Etniciteit, natievorming en verkiezingen in Suriname. In Jack Menke (ed.), Natievorming en natiecreatie in Suriname. Paramaribo: Stichting Wetenschappelijke Informatie, pp. 115-35. 
Bolland, O. Nigel, 2004. The Birth of Caribbean Civilization: A Century of Ideas about Culture and Identity, Nation and Society. Oxford: James Currey.

Brautigam, Ellen, 1999. Louis Doedel: Vergeten Surinaams vakbondsleider. [Hilversum, the Netherlands]: RVU Educatieve Omroep.

BREUNISSEN, KLAAS, 2001. Ik heb Suriname altijd liefgehad: Het leven van de Javaan Salikin Hardjo. Leiden, the Netherlands: KITLV.

DEW, EDWARD, 1993. Suriname: Transcending Ethnic Politics the Hard Way. In Ralph Premdas (ed.), The Enigma of Ethnicity: An Analysis of Race in the Caribbean and the World. St. Augustine: University of the West Indies, School of Continuing Studies, pp. 61-83.

ENCKEVORT, MARIA GERTRUDIS VAN, 2000. The Life and Work of Otto Huiswoud: Professional Revolutionary and Internationalist (1893-1961). PhD thesis University of the West Indies, Kingston.

HELMAN, ALBERT, 1995. Kroniek van Eldorado: Boek II. Gefolterden zonder verweer. Amsterdam: In de Knipscheer.

HIRA, SANDEW, 1982. Van Priary tot en met De Kom: De geschiedenis van het verzet in Suriname, 1630-1940. Rotterdam: Futile.

Hoefte, Rosemarisn, 1998. In Place of Slavery: A Social History of British Indian and Javanese Laborers in Suriname. Gainesville: University Press of Florida.

JAMES, C.L.R., 1989. The Black Jacobins: Toussaint L'Ouverture and the San Domingo Revolution. New York: Vintage Books. [Orig. 1938.]

JANSEN VAN GALEN, JOHN, 2003. Voorwoord bij de negende druk. In Anton de Kom, Wij slaven van Suriname. Amsterdam: Contact, pp. 7-16.

JOHNSON, RICHARD, 1982. Reading for the Best Marx: History-Writing and Historical Abstraction. In Richard Johnson, Gregor McLennan, Bill Schwarz \& David Sutton, Making Histories: Studies in History-Writing and Politics. London: Hutchinson, pp. 153201.

KAGIE, RUDIE, 2006. De eerste neger. Amsterdam: Mets \& Schilt.

KeMPEN, Michiel VAN, 1998. Wat verwaait er op de passaat? Of: Hoe de geest van Multatuli de krabben in de Surinaamse ton weerstond. In Theo D'haen \& Gerard Termorshuizen (eds.), De geest van Multatuli: Proteststemmen in vroegere Europese koloniën. Leiden, the Netherlands: Rijksuniversiteit Leiden, Vakgroep Talen en Culturen van Zuidoost-Azië en Oceanië, pp. 184-213.

-,2003a. Een geschiedenis van de Surinaamse literatuur: Band 1: 1596-1957 \& de orale literatuur. Breda, the Netherlands: De Geus.

—, 2003b. Van ijskast en bromfiets: Antillianen over Suriname, Surinamers over de Antillen en Aruba. In: Literatuur in Aruba in Caraïbisch perspectief: Symposiumbundel ter gelegenheid van het afscheid van Wim Rutgers van de Universiteit van Aruba. [Oranjestad]: Universiteit van Aruba, pp. 20-37. 
Kinshasa, Kwando M., 2002. From Surinam to the Holocaust: Anton de Kom, a Political Migrant. Journal of Caribbean History 36:33-68.

Kom, ANTON DE, [1969]. Strijden ga ik. Leiden, the Netherlands: Stichting tot Behoud en Stimulatie van Surinaamse Kunst, Kultuur en Wetenschap.

—, 2003. Wij slaven van Suriname. Amsterdam/Antwerpen: Contact. [Orig. 1934.]

LIER, R.A.J. VAN, 1979. Frontier Society: A Social Analysis of the History of Surinam. The Hague: Martinus Nijhoff. [Orig. 1971.]

MARS, PERRY, 2003. The Race-Class Problematic and the Caribbean Left. In Holger Henke \& Fred Reno (eds.), Modern Political Culture in the Caribbean. Kingston: University of the West Indies Press, pp. 59-89.

MARShALl, EDWIN KENNETH, 2003. Ontstaan en ontwikkeling van het Surinaams nationalisme: Natievorming als opgave. Delft, the Netherlands: Eburon.

MeEKS, BRIAN, 1996. Re-Reading The Black Jacobins: James, the Dialectic and the Revolutionary Conjuncture. In Brian Meeks, Radical Caribbean: From Black Power to Abu Bakr. Kingston: The Press University of the West Indies, pp. 102-23.

MEEL, PETER, 1999. Tussen autonomie en onafhankelijkheid: Nederlands-Surinaamse betrekkingen 1954-1961. Leiden, the Netherlands: KITLV.

—, 2001. Menselijke waardigheid als voertuig van emancipatie: Surinaamse geschiedschrijving en geschiedschrijving over Suriname. Oso 20:224-40.

—, 2008. Terughoudende staat, opkomende natie: Surinaamse helden en heldinnen. In Rosemarijn Hoefte, Peter Meel \& Hans Renders (eds.), Tropenlevens: De (post)koloniale biografie. Amsterdam/Leiden, the Netherlands: Boom/KITLV, pp. 236-62.

MOORE TURNER, JOYCE, 2005. Caribbean Crusaders and the Harlem Renaissance. With the Assistance of W. Burghardt Turner. Chicago: University of Illinois Press.

Mulier, Ludwig VAn, 2008. Anton de Kom 22 februari 1898 tot 24 april 1945. [Paramaribo]: Afaka International.

NecK-Yoder, Hilda VAN (ed.), 1998. Caribbean Literature from Suriname, the Netherlands Antilles, Aruba, and the Netherlands: A Special Issue. Callaloo 21:441-724.

OOSTINDIE, GERT, 1986. Kondreman in Bakrakondre: Surinamers in Nederland 16671954. In Gert Oostindie \& Emy Maduro, In het land van de overheerser II: Antillianen en Surinamers in Nederland 1634/1667-1954. Dordrecht, the Netherlands: Foris Publications, pp. 1-131.

-, 1990. De onvoltooide dekolonisatie en de geschiedschrijving van Suriname. Leidschrift 6(2):5-26.

-, 2004. Wij slaven van Suriname en het intellectuele eigendom van het koloniale verleden. In Michiel van Kempen, Piet Verkruijsse \& Adrienne Zuiderweg (ed.), Wandelaar onder de palmen: Opstellen over koloniale en postkoloniale literatuur en cultuur. Leiden, the Netherlands: KITLV, pp. 495-505. 
- \& ROSEMARIJN HOEFTE, 1999. Historiography of Suriname and the Netherlands Antilles. In B.W. Higman (ed.), General History of the Caribbean: Volume VI. Methodology and Historiography of the Caribbean. London/Oxford: UNESCO/Macmillan, pp. 604-30.

PARA, THEO, 1989. A. de Kom, grondlegger van de Surinaamse communistische gedachte. In Anton de Kom-Abraham Behr Instituut (comp.), A. de Kom: Zijn strijd en ideeën. Amsterdam: Sranan Buku, pp. 91-130.

PAZ, MAGDELEINE, 1933. Omdat ik zwart ben. Amsterdam: Querido. [Orig. 1930.]

SCHOLTENS, Ben, 1986. Opkomende arbeidersbeweging in Suriname: Doedel, Liesdek, De Sanders en De Kom en de werklozenonrust 1931-1933. Nijmegen, the Netherlands: Masusa.

—, 1987. Louis Doedel: Surinaams vakbondsleider van het eerste uur: Een bronnenpublikatie. Paramaribo: Anton de Kom Universiteit van Suriname.

—, 1989. "Wij slaven” van Anton de Kom: Gecensureerd? SWI Forum 6:9-21.

SCOTT, DAVID, 1999. Refashioning Futures: Criticism after Postcoloniality. Princeton: Princeton University Press.

-, 2004. Conscripts of Modernity: The Tragedy of Colonial Enlightenment. Durham NC: Duke University Press.

SMEULDERS, JACQUES, [1944]. De opperste tragedie van den neger is schaamte over het ras. [Willemstad]: Surinaamse Katholieke Kring "Sint Aloysius".

Solow, BArbara L. \& STANLEy L. Engerman (eds.), 1987. British Capitalism and Caribbean Slavery: The Legacy of Eric Williams. Cambridge: Cambridge University Press.

STIPRIAAN, ALEX VAN, WALDO HEILBRON, ASPHA BIJNAAR \& VALIKA SMEULDERS, 2007. Op zoek naar de stilte: Sporen van het slavernijverleden in Nederland. Leiden/ Amsterdam, the Netherlands: KITLV/NiNsee.

TINKER, HuGH, 1974. A New System of Slavery: The Export of Indian Labour Overseas, 1830-1920. London: Oxford University Press.

TORReS-SAiLlant, SiLVIO, 2006. An Intellectual History of the Caribbean. New York: Palgrave Macmillan.

VerheiJ, Elma \& Gerard VAn WeSterloO, 1984. De weg terug naar Java. Vrij Nederland 51/52:3-47.

WheEn, Francis, 2006. Marx' Das Kapital: A Biography. London: Atlantic Books.

WICART, ELLEN, 1990. Wanhoop en heilsverwachting: Oorzaken van het succes van Anton de Kom onder de Javaanse bevolking. Oso 9(2):83-99.

WILlIAMS, ERIC, 1994. Capitalism \& Slavery. Chapel Hill: University of North Carolina Press. 
WiJNEN, NiCO, 1989. A. de Kom: Niet bij woorden alleen. In Anton de Kom-Abraham Behr Instituut (comp.), A. de Kom: Zijn strijd en ideeën. Amsterdam: Sranan Buku, pp. 11-31.

\section{PETER MEEL}

Department of History

Leiden University

2300 RA Leiden, The Netherlands

$<$ P.J.J.Meel@hum.leidenuniv.nl> 